\title{
Edible mushrooms of the genus Pleurotus as biocontrol agents of parasites of importance for livestock
}

\section{Los hongos del género Pleurotus como agentes de biocontrol de parásitos de importancia pecuaria}

\author{
Tania María Rodríguez-Barrera1,2, Maura Téllez-Téllez², José E. Sánchez³, Gloria Sarahí Castañeda-Ramirez, \\ Ma. de Lourdes Acosta-Urdapilleta², Carlos Ramón Bautista-Garfias ${ }^{1}$, Liliana Aguilar-Marcelino ${ }^{1}$

\begin{abstract}
${ }^{1}$ Centro Nacional de Investigación Disciplinaria en Salud Animal e Inocuidad, INIFAP, km 11 carretera federal Cuernavaca-Cuautla, No. 8534, Col. Progreso, C.P. 62550, Jiutepec, Morelos, México.

${ }^{2}$ Centro de Investigaciones Biológicas de la Universidad Autónoma del Estado de Morelos Av. Universidad No. 1001, Col. Chamilpa

Cuernavaca, C.P. 62209, Morelos, México.
\end{abstract} \\ ${ }^{3}$ El Colegio de la Frontera Sur, km 2.5 carretera al Antiguo Aeropuerto, C.P. 30700, Tapachula, Chiapas, México.
}

\section{RESUMEN}

Antecedentes: Los hongos comestibles presentan propiedades nutracéuticas principalmente para los humanos, animales y plantas. Las especies de Pleurotus representan una alternativa de control de parásitos ya que tienen actividad nematicida contra diferentes géneros taxonómicos de nematodos de importancia pecuaria.

Objetivo: Presentar un panorama general sobre los hongos del género Pleurotus y sus características como método sustentable de biocontrol de nematodos parásitos de animales de importancia en salud pública.

Métodos: La revisión bibliográfica se llevó a cabo consultando estudios publicados sobre el género del hongo Pleurotus y sus propiedades, analizando lo referente a la actividad nematicida. Los trabajos fueron agrupados de acuerdo con su enfoque de investigación de trabajos en revistas indexadas y en la plataforma (Google academico), digital relacionada con palabras clave y temas del área pecuaria.

Resultados y conclusiones: Pleurotus spp. cuenta con diferentes metabolitos secundarios con actividad antiparasitaria principalmente antihelmíntica y particularmente contra nematodos gastrointestinales. Las características que tiene este hongo son excelentes para sus aplicaciones biotecnológicas ya que presenta una amplia gama de metabolitos secundarios en diferentes partes como son los basidiomas, el micelio y el sustrato degradado. Existen nuevas líneas de investigación que se deberán atender para demostrar su eficacia en biocontrol en el área pecuaria.

Palabras clave: hongos comestibles, antagonistas naturales, nematodos gastrointestinales, ganadería sustentable

\section{ABSTRACT}

Background: Edible mushrooms have nutraceutical properties, mainly in humans, animals and plants. Pleurotus species represent an alternative approach to parasite control because they have nematicidal activity against different taxonomic genera of nematodes of importance for livestock.

Objective: To present a general overview of fungi of the genus Pleurotus and their characteristics as a sustainable method of biocontrol for parasitic nematodes of animals with importance in public health.

Methods: This bibliographic review was carried out by consulting published studies on edible fungi of the genus Pleurotus and analyzing their properties related to nematicidal activity. The works were grouped according to their research focus; works related to keywords and topics in livestock were identified in indexed journals and on digital platforms (academic Google).

Results and conclusions: Pleurotus spp. produce different secondary metabolites with antiparasitic activities, mainly anthelmintic and particularly against gastrointestinal nematodes and their larval stages. The characteristics of these fungi are excellent for biotechnological applications since they produce a wide range of secondary metabolites in different parts, such as in the basidiomata, mycelia and degraded substrates. There are new lines of research that must be addressed to demonstrate their effectiveness in the area of biocontrol in livestock.

Keywords: Edible mushrooms, natural antagonist, gastrointestinal nematodes, sustainable livestock

\section{ARTICLE HISTORY}

Received 24 September 2020

Accepted 19 February 2021

Published on line: 16 March 2021

\section{CORRESPONDING AUTHOR}

Liliana Aguilar Marcelino, aguilar.liliana@inifap.gob.mx ORCID: 0000-0002-8944-5430

José E. Sánchez, esanchez@ecosur.mx

ORCID: 0000-0003-0535-4302 


\section{INTRODUCTION}

Livestock farming is one of Mexico's most important economic activities, and the country is ranked seventh in the world as a powerhouse in the generation of livestock products (FAO 2020). Livestock is a cost-effective sector that guarantees the production and supply of accessible, safe and quality food (Figueroa-Antonio et al. 2018). The livestock sector is affected by different diseases caused by parasites, such as gastrointestinal nematodes (GIN), which represent one of the most important health problems in livestock worldwide (Pinilla et al. 2018). Subclinical infections and the presence of GIN are determined by biotic and abiotic factors, such as climate, animal management and the age of hosts exposed to contaminated pastures (Byron et al. 2018). Parasitism caused by GIN causes economic losses in Mexico estimated at 35 billion pesos per year (FAO 2020). The economic losses are mainly caused by a decrease in milk and meat production and an increase in the costs associated with treatment and control of GIN (Pinilla et al. 2018).

Given this problem, it is essential to carry out studies to identify sustainable alternatives to control highly prevalent gastrointestinal parasites, as well as to understand their epidemiology and susceptibility to anthelmintic drugs (Byron et al. 2018).

Chemical products (e.g., macrocyclic lactones) used in an inadequate and constant manner can cause anthelmintic resistance (Lumaret et al. 2012, Márquez-Lara 2013). Additionally, the use of these chemical products threatens the environment (Martínez and Cruz 2009). Medicines, such as fenbendazole and oxfendazole, are excreted by ruminants in large quantities and put beneficial organisms, such as dung beetles (Onthophagus landolti and Aphodius rufipes), earthworms and nematophagous mites (Caloglyphus mycophagus), at risk (Aguilar-Marcelino et al. 2016, Quintero 2018).

Biocontrol can serve as an alternative to chemical products (Al-ani et al. 2020). Fungi are antagonists of parasitic nematodes of vertebrate animals, plants, insects and other pathogenic fungi (Fernández-Jiménez et al. 2019). They are excellent biocontrol agents due to their high reproductive capacity, specificity, production of resistant spores or development of saprophytic phases in the absence of their hosts, and antagonistic activities (Fernández-Jiménez et al. 2019). Barron and Thorn (1987) reported the mechanism of attack of $P$. ostreatus against the free-living nemato- de Rhabditis spp. Initially, the mycelium of the fungus produces toxocysts, which are mainly composed of a nematotoxin called ostreanin, to attract the nematodes. Once the nematodes have made contact with the ostreanin, they become immobilized and the mycelium quickly penetrates their body through the oral cavity, anus and intercuticular spaces, allowing the fungus to subsequently feed on the nematode. The species of Pleurotus that showed this nematicidal activity are $P$. strigosus, $P$. subareolatus and P. cornucopiae. In addition, Li and Zhang (2014) reported 23 species of the genus Pleurotus with nematicidal activity. Based on the information that has been described to date, the objective of the present review was to analyze the characteristics of the genus Pleurotus as a biocontrol agent of parasites of importance for livestock.

\section{PARASITES OF IMPORTANCE TO LIVESTOCK}

A parasite is an organism that lives in another organism from which it feeds (SENASA 2017, Gutiérrez et al. 2020). Animals can become infected with parasites and can spread the infection. The animal on which the parasite feeds is called the host. The main helminths include the hematophagous nematode (Haemonchus contortus), cestodes (Taenia saginata) and trematodes (Fasciola hepatica) (SENASA 2017, Gutiérrez et al. 2020).

The GIN are found within the organs of the digestive tract, where copulation takes place between males and females, which produces eggs that are disposed of into the environment along with the animal's feces (Sutherland and Scott 2010). There are also other parasites that cause intestinal trichostrongylosis. The most important genera from a veterinary point of view are Trichostrongylus, Cooperia and Nematodirus (Von son-De-Fernex et al. 2016, Pinilla et al. 2018).

Gastroenteric parasitosis in ruminants mainly bovines and sheep are very important due to their cosmopolitan nature, causing great economic losses that can be direct such as the death of young animals or indirect that are clinically manifested by persistent diarrhea, anemia and malnutrition, resulting in stunted growth in young animals, as well as low production of meat and milk in adult animals (Valcárcel-Sancho et al. 2009, Liébano et al. 2011). In table 1, the most important gastrointestinal parasites (nematodes) of ruminants are presented. 
Table 1. Gastrointestinal parasites (nematodes) of ruminants

\begin{tabular}{|c|c|}
\hline Species & Organ \\
\hline Haemonchus contortus & Abomasum \\
\hline H. placei & Abomasum \\
\hline Mecistocirrus digitatus & Abomasum \\
\hline Trichostrongylus axei & Abomasum \\
\hline T. colubriformis & Abomasum \\
\hline T. longispicularis & Abomasum \\
\hline Teladorsagia/Ostertagia circumcincta & Abomasum \\
\hline O. trifurcata & Abomasum \\
\hline O. lyrata & Abomasum \\
\hline Nematodirus spathiger & Small intestine \\
\hline N. fillicolis & Small intestine \\
\hline N. helvetianus & Small intestine \\
\hline N. battus & Small intestine \\
\hline Strongyloides papillosus & Small intestine \\
\hline Bunostomum trigonocephalum & Small intestine \\
\hline B. phlebotomum & Small intestine \\
\hline Cooperia oncophora & Small intestine \\
\hline C. pectinata & Small intestine \\
\hline Trichostrongylus spp. & Small intestine \\
\hline Toxocara vitulorum & Small intestine \\
\hline
\end{tabular}

In rural areas of the country, animal husbandry is the main activity that supports the economy of producers and their families (López-González et al. 2012). However, this activity is carried out under precarious conditions that make the animals vulnerable to endemic diseases such as parasites; this has caused economic losses estimated at 35 billion pesos due to reductions in animal performance, deterioration of product quality and increased costs of prevention, control, treatment and animal death (FAO 2020). Parasitic diseases affect livestock production, as well as public health, and their risks are associated with production systems (SENASA 2017).

Parasites are very diverse and may vary from one region to another; however, the genera commonly found in Mexico are Haemonchus, Trichostrongylus, Cooperia, Strongyloides, Nematodirus, and Oesophagostomum (Rodríguez-Vivas et al. 2017).

Helminths are found in different climates thanks to their high reproductive capacity and various adaptation mechanisms in response to adverse environmental conditions. Parasite species in cattle prefer certain organs (Paredez-Martinez 2014). These parasites have a direct life cycle, with a free-living phase in the pasture and a parasitic phase in the animal. Most of these parasites infect animals via the oral route following ingestion of infectious larvae $\left(\mathrm{L}_{3}\right)$ present in water and food. Some factors favor the development of the parasites in the free-living phase, including humidity above $80 \%$ and temperatures between $25-27{ }^{\circ} \mathrm{C}$, which facilitate the evolution of the larvae over 7-10 days. Eggs are excreted with sheep feces into the grass, there they hatch into the larval stage and some migrate to pastures in water films, while others remain on the damp surface of the ground and manage to survive for months. In the dry season, larvae prefer wet sites because drying is detrimental to their survival (Paredez-Martinez 2014).

\section{Haemonchus contortus}

Haemonchus contortus is a nematode with blood-sucking habits, and it has 16 intestinal cells and a protective sheath in its infective stage $\left(L_{3}\right)$ (Zajac and Garza 2020). While $H$. contortus is more prevalent in tropical climates, it is also present in various parts of the world and has a negative impact on the livestock sector ( $\mathrm{Wi}$ diarso et al. 2018).

\section{Life cycle of Haemonchus contortus}

The life cycle of the sheep parasitic nematode $H$. contortus is divided into two phases: 1) exogenous and 2) endogenous. The exogenous phase begins when the sheep expel the eggs into the pasture in their feces; under optimal conditions, the $L_{1}$ larvae develop. This occurs in 1-2 days, after which the eggs hatch and the free-living larvae $\left(L_{2}\right)$ emerge. After seven days, they reach their infective stage, known as $L_{3}$. These larvae migrate to the upper parts of the pastures to be ingested by the animals along with the grass (Zajac and Garza 2020). The endogenous phase starts when the infectious larvae $\left(L_{3}\right)$ have been ingested by the sheep, at which time it enters the digestive tract and develops into $L_{4}$ and later, into $L_{5}$. In this last stage the nematode is considered an adult (Sutherland and Scott 2010). It should be mentioned that stages $L_{4}$ and $\mathrm{L}_{5}$ feed on blood and tissue, and this activity irritates the mucosa causing inflammation. In addition, as the nematodes extract considerable amounts of blood, anemia develops, which is manifested as paleness of the conjunctiva and gums. At this stage, the animals become indifferent and suffer from low food conver- 
sion, their hair becomes brittle and dull, and the animals lose their appetite, rendering them unable to regain their normal weight, sometimes resulting in death (Gasque 2008) (Figure 1).

\section{Pest control in the livestock arena}

These parasites have traditionally been treated with regular administration of chemical drugs (anthelmintics) as a simple and "effective" way to alleviate parasitic diseases. However, many animals have high parasite loads and clinical features of parasitosis (Lobayan et al. 2017), as the parasites have developed resistance to the anthelmintic products administered (González-Garduño et al. 2003, Torres-Acosta et al. 2003, Lanusse et al. 2018).

Anthelmintic products are currently the main method used to control ruminant nematodes worldwide. They have different mechanisms of action, and avermectins, benzimidazoles and nicotinic agonists are the most common anthelmintics used in ruminants (Márquez-Lara 2013).
Ivermectins are one of the anthelmintics available and they are frequently used by producers. However, they have negative effects on the environment, especially on microfauna such as beneficial arthropod populations associated with feces (they mainly affect their larval forms) (Márquez-Lara 2013).

Anthelmintic resistance can be either intrinsic or acquired; in the former, a parasite is naturally resistant to an anthelmintic due to the absence of receptors or the inability of the product to enter the site of action, as occurs in the resistance of trematodes and cestodes to macrocyclic lactones. Acquired resistance occurs in parasites that were originally susceptible to the drug, but after genetic modifications of the parasite that become hereditary, they are no longer susceptible (Márquez-Lara 2013, Olazarán-Jenkins et al. 2019).

Sustainable alternatives: edible mushrooms

An alternative method for parasite control in the livestock arena is edible mushrooms. Ascomycete, ba-

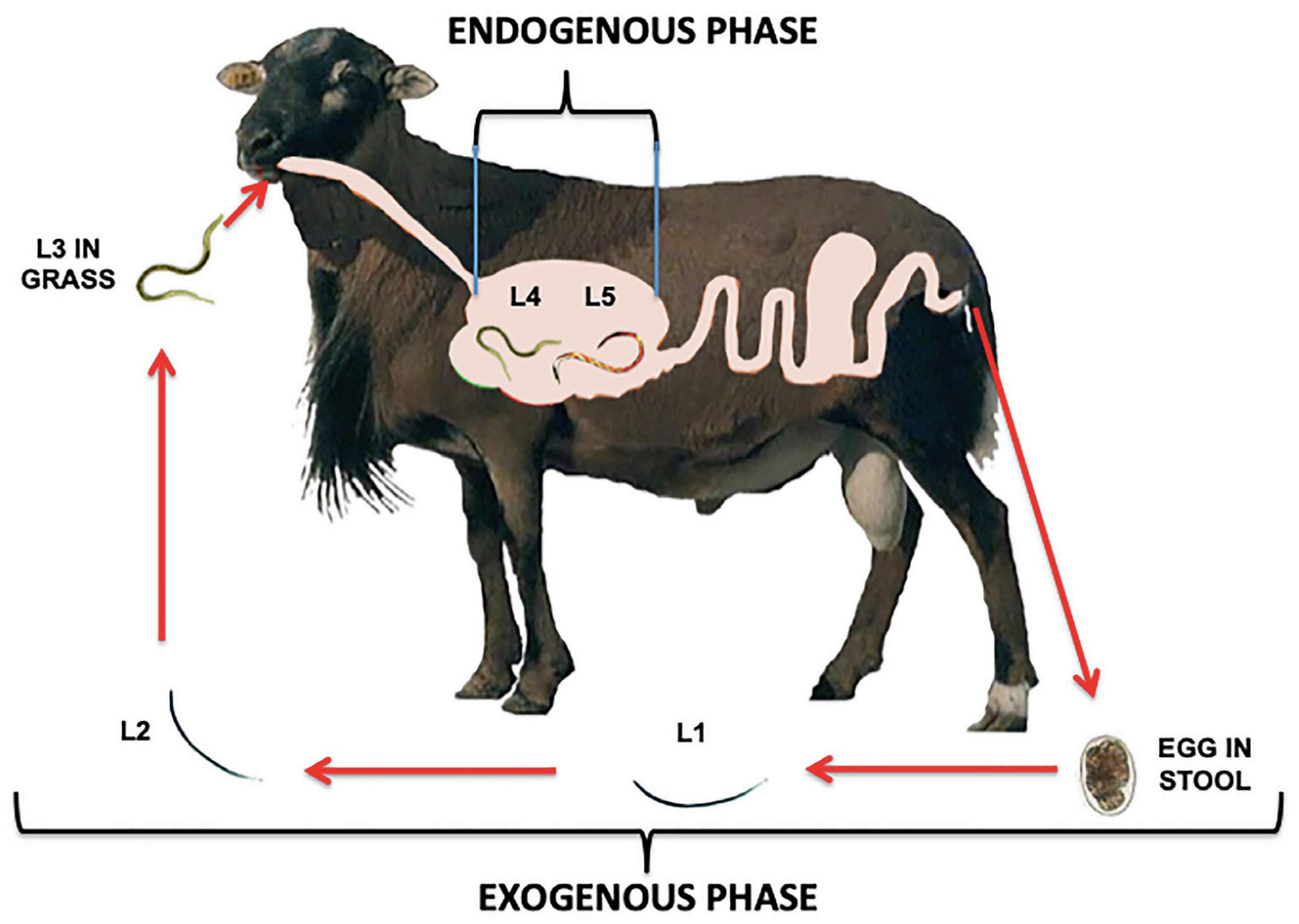

Figure 1. The biological cycle of nematode Haemonchus contortus. The exogenous phase showing the develop from eggs to the infectious larvae $\left(L_{3}\right)$ and the endogenous phase showing the develop of the $L_{3}$ to $L_{5}$. 
sidiomycete and zygomycete fungi have developed various strategies to attack nematodes, which are the most abundant organisms in the soil. They have developed these mechanisms to obtain the nitrogen requirements (van den Hoogen et al. 2019). In fact, Hyde et al. (2014) was the first to report a fungus with the capacity to trap nematodes corresponding to the species Palaeoanellus dimorphus, which lived 100 million years ago and are probably extinct today. Currently, fungi with nematicidal activity are distributed throughout the world. According to Li and Zhang (2014), there are 280 species belonging to 150 genera between the ascomycetes and basidiomycetes that have nematicidal capacity.

Barron and Dierkesy (1977) established that some species of Hohenbuehelia, and its anamorph Nematoctonus, had anthelmintic capacity. Furthermore, Barron and Thorn (1987) reported that the genus Pleurotus was more versatile than Hohenbuehelia because in addition to nematodes, other organisms could also serve as nutrients.

On the other hand, there are also nematodes that parasitize edible mushrooms and cause serious problems in their development and productivity. The most documented case is Agaricus bisporus, although the genus Pleurotus is not exempt from their attack (Belletini et al. 2018, Singh and Sharma 2016). Finally, there is also the case of beneficial nematodes for edible mushrooms that, being antagonists of their pests, are useful in biological control strategies (Choo et al. 2001, Rinker et al. 1995).

\section{CLASSIFICATION OF NEMATOPHAGOUS FUNGI}

Fungi are organisms that possess the ability to attack, kill and digest the body of nematodes (Rodríguez-Martínez et al. 2018). It has been observed that the mycelium of edible fungi can infect nematode eggs (Nordbring-Hertz et al. 2006). In addition to their nematicidal ability, these fungi can also live saprophytically on dead organic matter, and they can attack other fungi (mycoparasites) and colonize plant roots as endophytes (Nordbring-Hertz et al. 2006). These fungi described below (Hyde et al. 2014), are divided into four groups depending on their mechanism of action. The nutrients obtained by the fungi from the nematodes are used to form new fungal structures.
1) Trap forming fungi

These fungi form various types of trapping organs in their hyphae. There are two different mechanisms that function in the traps: adhesive and mechanical. Whatever the mechanism, the fungus can penetrate the cuticle of the nematode through the trap, forming a bulb of infection inside the nematode, from which the trophic hyphae grow inside the body and digest its contents (Nordbring-Hertz et al. 2006, Saumell et al. 2008, Mendoza-de-Gives and Valero-Cross 2009, Castañeda-Ramírez et al. 2016, Aguilar-Marcelino et al. 2017a, Mendoza-de-Gives 2020).

\section{2) Endoparasitic fungi}

Endoparasites use their spores to infect nematodes. These fungi are often forced parasites of nematodes, and they appear only as structures of dissemination outside the infected body of the nematode. The spores of these fungi adhere to and penetrate the cuticle of the nematode, thereby becoming embedded in it (Nordbring-Hertz et al. 2006, Zhang et al. 2011).

\section{3) Ovicidal fungi}

These fungi infect nematode eggs and produce appressoria (infection structures at the ends of the hyphae that attach to the egg cover). The fungi penetrate the egg cover and digest the contents (Nordbring-Hertz et al. 2006).

\section{4) Toxin-producing fungi}

The most common fungus in this group is the wood decomposer $P$. ostreatus, along with other species of the genus Pleurotus. This type of fungus contains a toxin in its hyphae; after contact with the toxin, the nematode is quickly immobilized. The fungal hyphae then grow chemotropically through the mouth of the nematode, digesting it, similar to the nematophagous fungi (Nordbring-Hertz et al. 2006).

The majority of these fungi belong to the basidiomycetes, for example, the genera Pleurotus and Coprinus; however, other fungi within the ascomycetes (Lecanicillium, Paecilomyces, and Pochonia) also produce nematicidal compounds. The fungus Paecilomyces lilacinus secretes acetic acid that paralyses young nematodes (Djian et al. 1991), and bioactive compounds have also been isolated from in vitro cultures of Pochonia chlamydosporia. Currently, more than 270 species 
of fungi have been reported to produce nematicidal compounds (Zhang et al. 2011).

Coprinus comatus has been reported to immobilize the activity of Panagrellus redivivus via two strategies (Luo et al. 2007). The first is through spiny spherical structures (toxocysts) (Armas-Tizapantzi et al. 2019) that attract nematodes; when the toxocysts come into contact with the cuticle, they immobilize the nematode and the fungal mycelia invades the body and degrades it (Barron and Thorn 1987, Al-ani et al. 2020).

The second strategy involves the production of various products including toxins, such as ostreatin/ trans-2-decanoacid, linoleic acid peroxide and extracellular proteases (serine proteases) (Kwok et al. 1992); proteins (Cuevas-Padilla 2019), such as ostreolysin, amatoxin, coprin, phaloxin and acromelic acid; and secondary metabolites, including cheimonophyllon $E$ and 5-hydroxymethyl-furancarbaldehyde in P. ferulae, trans-2-decenedioic acid from $P$. ostreatus, and p-anisaldehyde, p-anisyl alcohol, 1-(4-methoxyphenyl)-1,2-propane-diol, 2-hydroxy-(4'-methoxy)-propiophenone, S-choriolic acid and linoleic acid from $P$. pulmonarius (Cuevas-Padilla et al. 2018, Pineda-Alegría et al. 2017, 2020, Castañeda- Ramírez et al. 2020).

\section{IMPORTANT ASPECTS OF THE GENUS PLEUROTUS}

\section{Pleurotus spp.}

White rot fungi, such as Pleurotus species, are considered primary decomposition agents because they are able to use agricultural waste in its original form (i.e., not previously subjected to any biochemical or microbiological degradation process) (Camacho-Morales et al. 2017). Several species of edible mushrooms are currently cultivated on an industrial scale. This provides an excellent alternative use for these fungi, as they grow abundantly on coffee pulp (Coffea arabica), sugar cane bagasse (Saccharum officinarum) and henequen (Agave fourcroydes), among other diverse lignocellulosic materials (Salmones and Mata 2012, Sánchez and Royse 2017).

Pharmacological studies of the genus Pleurotus have been carried out on different parts of the fungus, such as the fruiting body, also known as basidiocarp, carpophore or sporophore, and the mycelium, as well as from the degraded substrate. Different extracts and metabolites, such as phenolics, polypeptides, terpenes, sterols and polysaccharides, among others, have been obtained from the fungal materials described above (Ribeiro et al. 2006). Among these metabolites, the most studied are the polysaccharides obtained from the fruiting bodies and mycelia of several species, including P. ostreatus, P. sajor-caju and P. citrinopileatus (Gómez-Velázquez 2018).

Species of genus Pleurotus have different medicinal and therapeutic properties including anti-inflammatory (Smiderle et al. 2008, Gómez-Velázquez 2018), antihypertensive, cardiotonic (Gómez-Velázquez 2018), antiviral, antimicrobial, cytotoxic, antitumor, anticarcinogenic and antioxidant activities (Sánchez et al. 2015). Metabolites, such as lovastatin and others of phenolics, flavonoids and tannins, have been identified and isolated from edible wild mushrooms including $P$. ostreatus and P. djamor. Of the main phenolic compounds found in the genus Pleurotus, those derived from benzoic acid (gallic and syringic acid) and cinnamic acid (ferulic and caffeic acid) stand out (Oropeza 2017).

Based on their immunomodulatory activity, the fungi of the genus Pleurotus have been further studied as a natural source of bioactive compounds capable of complementing or stimulating a desired immune response in the host. These products include substances of high molecular weight, mainly polysaccharides of the type $\beta-(1,3)-(1,6)$-D-glucans, proteins, proteoglycans and polysaccharide-protein complexes, as well as different secondary metabolites of low molecular weight (Quevedo et al. 2018).

Insecticide activity has also been reported. Extracts from the species $P$. ostreatus have insecticidal properties against Tribolium castaneum and Macrosiphum rosae, with higher insect toxicity observed as the time of extract exposure increases (Pérez-Moreno et al. 2010). Another property of $P$. ostreatus is its ability to biodegrade organophosphate insecticides in the soil. This is because it secretes several extracellular enzymes that degrade a great variety of natural and anthropogenic compounds, which have chemical structures similar to lignin (Pino et al. 2019). Pleurotus ostreatus also has antiparasitic and anthelmintic (nematicide and cestocides) properties (Pérez-Moreno et al. 2010, Salmones and Mata 2012, Aguilar-Marcelino et al. 2017b).

Studies carried out by Thorn and Barron (1984) mention five species of Pleurotus, Pleurotus strigosus, $P$. subareolatus, $P$. cornucopiae, $P$. cystidiosus and $P$. ostreatus, which each present a different capacity to attack and consume nematodes, suggesting that the- 
se fungi use the nutrients of their prey (nematodes) to complement the low levels of nitrogen available in wood. This mode of obtaining nutrition is similar in principle to that of the superior "carnivorous" plants. Hibbet and Thorn (1994) also indicated that the genus Pleurotus, sensu Singer, displayed a typical form of nematode capture that seemed characteristic of the genus; they suggested that this could be adequate for identifying members of the genus. They mention the positive activity of the species $P$. cornucopiae, $P$. cystidiosus, P. levis, P. ostreatus, P. populinus, $P$. subareolatus, $P$. pulmonarius, $P$. dryinus, $P$. euosmus, and $P$. eryngii. Additionally, Sharma (1994) reported that the breeding ground of Pleurotus sajor-caju can immobilize the nematodes of the mushroom Agaricus bisporus and more recently, the species $P$. djamor has also been reported to have anthelmintic activity (Pineda-Alegría et al. 2017).

The fungus $P$. tuberregium is a common basidiomycete found in tropical climates in Africa and Australia. Studies show that the sclerotia of this fungus are formed under the soil because the basidiocarpus has skeletal hyphae interspersed (Gilbertson 1981). Hibbet and Thorn (1994) reported the capture of the free-living nematode Rhabditis sp. by $P$. tuberregium. Cultivated in water-agar, the fungal mycelia produced toxin droplets, and when the nematodes came into contact with the toxin droplets, they became paralyzed and then colonized by the fungal hyphae. This mode of nematode capture has been previously demonstrated only in Pleurotus species genus, sensu stricto.

Regarding the nematicidal activity of the genus Pleurotus, several studies have been carried out on diffe- rent stages of the sheep parasite nematode $\mathrm{H}$. contortus, including the eggs, infectious larva $\left(L_{3}\right)$ and histotrophic larva $\left(L_{4}\right)$ (Aguilar-Marcelino et al. 2017b). Additionally, a biodirected chemical study has been reported by González-Cortazar et al. (2020); an initial chromatographic fractionation of the hydroalcoholic extracts of the fruiting bodies of $P$. djamor was carried out to identify and isolate the metabolites responsible for its nematicidal activity. The PdR2 fraction and the $\mathrm{PdB}$ subfraction obtained from the extract fractionation were evaluated in vitro against the nematode $H$. contortus. Additional evaluations were carried out in a gerbil model to determine the nematicidal effects of the PdB fraction. Finally, gas-mass chromatography analyses, including spectrometry and nuclear magnetic resonance, of the PdB fraction were performed. The results showed that $100 \%$ egg hatching occurred with $5 \mathrm{mg} / \mathrm{mL}$ of the PdB fraction. The larvicidal activity was $>97.2 \%$ after $24 \mathrm{~h}$ with $20 \mathrm{mg} / \mathrm{mL}$. The in vivo evaluation of the $\mathrm{PdB}$ fraction showed a $92.56 \%$ reduction in $\mathrm{H}$. contortus larvae. The compounds present in this fraction were a mixture of "allitol" and an unidentified terpene at a proportion of 9:1.

Next, some compounds that have been isolated from different species of Pleurotus genus with activity against different taxonomic genera of parasitic and free-living nematodes are presented (Table 2).

\section{Pleurotus ostreatus}

Known as white ears and oyster mushrooms, Pleurotus ostreatus has a cap in the shape of a shelf, is 4-14 $\mathrm{cm}$ in diameter, and whitish, gray or grayish-brown in color. Its gills are decurrent and whitish, and it has a

Table 2. Isolated compounds from different species of Pleurotus genus

\begin{tabular}{|c|c|c|c|}
\hline Species & Nematicide compound & Concentration & Reference \\
\hline P. ostreatus & Trans-2-decenedioic acid & $95 \%$ & Kwok et al., 1992 \\
\hline P. pulmonarius & p-anisaldehyde, p-anisyl alcohol & $75 \%$ & Stadler et al. 1994 \\
\hline P. ferulae & Cheimonophyllon E, 5-hydroxymethyl-furancarbaldehyde & $50 \%$ & Li et al., 2001, 2007 \\
\hline P. pulmonarius & 1-(4-methoxyphenyl)-1,2-propanediol & $75 \%$ & Koitabashi et al. 2004 \\
\hline P. ostreatus & 2-hydroxy-(4'-methoxy)-propiophenone & $87-94 \%$ & Koitabashi et al. 2004 \\
\hline P. eryngii & S-coriolic acid & $95 \%$ & Xiang and Feng 2001 \\
\hline
\end{tabular}


short side stipe, which can sometimes be eccentric. The meat or context of the mushroom is white or whitish, with a pleasant taste and smell. The fruiting bodies grow in a gregarious manner and are generally overlapping on fallen or standing trunks, or on various plant remains. This fungus is distributed across the world in temperate and tropical forests (Salmones and Mata 2012).

The species $P$. ostreatus represents an alternative for parasite control in the livestock sector, as it has nematicidal activity against different taxonomic genera of nematodes that infect livestock (e.g., the eggs and infectious and histotrophic larvae of $\mathrm{H}$. contortus), parasite nematodes of public health importance (e.g., Ancylostoma caninum) and free-living nematodes (e.g., Panagrellus redivivus) (Garcia-Lopes et al. 2015, Sanchez and Royse 2017).

The mechanism of action of edible mushrooms, particularly $P$. ostreatus, is carried out by structures known as "toxocysts" (Armas-Tizapantzi et al. 2019), which produce a nematotoxin called NRRL 3526 that acts against the bacteriophage nematode $P$. redivivus. At a concentration of $300 \mathrm{ppm}$, this toxin can induce 95 $\%$ lethality in these nematodes in one hour (Kwok et al. 1992). The fungal mycelia invade the body orifices, such as the anus and the mouth of the nematode, feeding on the body to obtain nutrients and continue their biological cycle. Trans-2-decenedioic acid is produced by $P$. ostreatus and is among the secondary metabolites responsible (Kwok et al. 1992).

Several studies have reported up to 84 metabolites isolated from $P$. ostreatus with nematicidal activity (Degenkolb and Vilcinskas 2016, Kwok et al. 1992). In addition, other compounds with nematicidal activity have been identified, such as alkaloids, quinones, peptides, terpenoids, fatty acids (e.g., pentadecanoic acid, palmitic acid, sitosterol and linoleic acid), and polyphenols ( $\mathrm{Li}$ and Zhang 2014, Pineda-Alegría et al. 2020). However, other species of fungi, such as Neolentinus ponderosus and Lentinula edodes (Montañez-Palma 2020), also have great potential in the search for bioactive products with nematicidal activity in the livestock arena.

Pleurotus ostreatus has been reported to produce a nematotoxin that can immobilize nematodes in a few minutes; however, the mechanism of action by which this paralysis occurs had not been established for this fungus-nematode interaction. Additionally, other studies have investigated the predatory relationship between free-living nematodes (Diplogastridae) and $P$. ostreatus as a potential method of exterminating other parasitic nematodes of plants, animals and public health importance. After nematode invasion, the fungus $P$. ostreatus defends itself by causing the nematode's head to shrink. This phenomenon suggests that this anti-nematode mechanism is associated with linoleic acid peroxide (Satou et al. 2008).

Lee et al. (2020) conducted a study showing that $P$. ostreatus paralyses the free-living nematode Caenorhabditis elegans through a mechanism that is evolutionarily conserved in different nematode species. They found that the sensory "cilia" of $C$. elegans triggered a massive influx of intracellular calcium and a hypercontraction of the muscles in the pharyngeal wall and body, which eventually induced necrosis of the neuromuscular system throughout the nematode's body.

Secondary metabolites of the genus Pleurotus and their activity against gastrointestinal nematodes

To date, various compounds with nematicidal activity have been isolated from fungal hyphae, including alkaloids, quinones, peptides, terpenoids, fatty acids, and polyphenols (Li and Shah 2014). This activity against nematodes is of great importance from the agricultural and livestock point of view, as well as in the biocontrol of pests since their action against phytopathogenic insects and fungi has also been mentioned. These characteristics make them excellent candidates as natural biocontrol agents.

The secondary metabolites responsible for this action include trans-2-decenedioic acid, produced by P. ostreatus, and s-coriolic acid, linoleic acid, p-anisaldehyde, p-anisyl alcohol. However, the importance of these metabolites is questionable, as it has been shown that they are produced only in specific areas of the hyphae, and morphological differentiation to form specialized structures, called toxocysts, has only been shown in a few cases (Armas-Tizapantzi et al. 2019).

Several studies have reported the anthelmintic activity of Pleurotus species. A work carried out by Cuevas-Padilla et al. (2018) demonstrated the in vitro effects of a bioactive fraction from Pleurotus species. This bioactive fraction was evaluated against several stages of $H$. contortus, and it was shown that $P$. ostreatus had a higher nematicidal activity than $P$. eryngii. Later, Cue- 
vas-Padilla (2019) carried out an in vitro evaluation of the proteins in raw extracts of five Pleurotus species $(P$. cornucopiae, $P$. djamor, $P$. eryngii, $P$. ostreatus and $P$. pulmonarius). The highest activity was obtained with P. pulmonarius, which was $81.2 \%$ lethal against $H$. contortus eggs. They also revealed lethal effects against $L_{1}, L_{3}$ and $L_{4}$, as well as mobility inhibition.

Comparisons between the different types of activities (i.e., paralysis by the raw extract, inactivation by the extracts, and a hydroalcoholic extracts) suggested the involvement of products of a proteinaceous nature. These results demonstrated the nematicidal potential of putative Pleurotus species. proteins against $\mathrm{H}$. contortus larvae. Arteaga-Paredes (2018) demonstrated the nematicidal and nematostatic potential of $P$. ostreatus in vitro against Globodera pallida larvae $\left(\mathrm{J}_{2}\right)$, a phytopathogenic nematode that generates losses of up to $30 \%$ in potato crop yields (Solanum tuberosum) in Ecuador.

The nematicidal and nematostatic activity of the filtered broth of $P$. ostreatus was studied over time $(8,12$ and $24 \mathrm{~h})$ and at four different concentrations $(0,50$, 75 and $100 \%)$. The results showed that the percent mortality was directly proportional to the filtrate concentration and the exposure time. The most effective combination was a concentration of $100 \%$ for $24 \mathrm{~h}$, which resulted in a mortality rate of $41.6 \%$; treatment with a concentration of $100 \%$ for $8 \mathrm{~h}$ resulted in the highest percent of immobilized nematodes (65.2\%). In another study (Aldaz 2018) it was reported that the fungus $P$. ostreatus has nematicidal activity. They initially obtained an extract using two solvents, acetone and methanol, through a Soxhlet extraction method. The nematodes used in these bioassays were Ditylenchus dipsaci and Panagrellus redivivus.

The acetone extract at a concentration of $75 \%$ induced $95 \%$ mortality in D. dipsaci and $92.55 \%$ mortality in $P$. redivivus. Another study reported by Pineda-Alegría et al. (2017) evaluated the in vitro activity of extracts and fractions of $P$. djamor against $H$. contortus eggs and $\mathrm{L}_{3}$ larvae. The results showed that most of the $P$. djamor extracts had no significant activity against the eggs; however, one extract induced $77-98.7 \%$ mortality in $\mathrm{L}_{3}$ larvae at $72 \mathrm{~h}$ post confrontation. Elucidation of the extract revealed several compounds including four fatty acids (pentadecanoic, hexadecenoic, octadecadienoic, and octadecanoic acid, and a terpene identified as $\beta$-sitosterol).

\section{CONCLUSIONS}

Edible mushrooms of the genus Pleurotus produce secondary metabolites with anthelmintic activity against gastrointestinal parasites in their larval stages. There is excellent potential in this fungal genus for biotechnological applications due to its biocontrol characteristics. There are new lines of research that should be addressed to demonstrate its effectiveness in the livestock arena, since metabolites and other compounds with anti-helminthic activity have been found in the mycelium, basidiomata, and degraded substrates where Pleurotus species had been cultivated. Among these potential investigations, the molecular approach stands out, as it is expected to help answer several questions, such as the mode of action and the conditions that predispose the fungus-nematode relationship.

\section{ACKNOWLEDGMENTS}

This review was funded by Problemas Nacionales of CONACYT with the project number: 9342634372.

\section{REFERENCES}

Aguilar-Marcelino L, Mendoza-de-Gives P, Quintero-Martínez MT, López-Arellano ME, Bautista-Garfias CR, Reyes-Guerrero DE, Olmedo-Juárez A. 2016. Cultivo in vitro de ácaros nematófagos Lasioseius penicilliger y Caloglyphus mycophagus como agentes de biocontrol. Quehacer Científico en Chiapas 11: 52-59.

Aguilar-Marcelino L, Mendoza-de-Gives P, Torres-Hernández G, López-Arellano ME, Becerril CM, Orihuela-Trujillo A, Torres-Acosta JFJ, Olmedo-Juarez A. 2017a. Consumption of nutritional pellets with Duddingtonia flagrans fungal chlamydospores reduced infective nematode larvae of Haemonchus contortus in faeces of Saint Croix lambs. Journal of Helminthology 91: 665-671. Doi: 10.1017/S0022149X1600081X

Aguilar-Marcelino L, Sánchez-Vázquez JE, Mendoza-de-Gives P. 2017b. Uso biotecnológico de productos obtenidos a partir de Pleurotus spp. en el control de nematodos parásitos de importancia pecuaria. In: Sánchez JE, Royse DJ (eds.), La biología, el cultivo y las propiedades nutricionales y medicinales de las setas Pleurotus spp. El Colegio de la Frontera Sur, San Cristobal de las Casas. Pp. 297-309.

Al-ani LKT, Aguilar-Marcelino L, Fiorotti J, Sharma S, Sharif M, Furtado EL, Wijayawardene NN, Herrera-Estrella A. 2020. Biological control agents and their importance for plant health. In: Singh JS, Raj Vimal S (eds.) Microbial services in restoration ecology. Elsevier, Cambridge. Pp. 42.

Aldaz-Merchán L. 2018. Evaluación de la actividad nematicida de los extractos acetónico y metanólico de Pleurotus ostreatus. Tesis de Licenciatura. Escuela Superior Politécnica de Chimborazo, Ecuador. 
Armas-Tizapantzi A, Mata G, Hernandez-Cuevas LV, Montiel-Gonzalez AM. 2019. Estructuras tipo toxocistos en Pleurotus ostreatus y P. pulmonarius. Scientia Fungorum 49: Doi: 10.33885/ sf.2019.49.1250

Arteaga-Paredes MB. 2018. Determinación del potencial nematicida y nematostático in vitro de Pleurotus ostreatus (Agaricales: Pleurotaceae) sobre larvas $\mathrm{J}_{2}$ de Globodera pallida (Tylenchida: Heteroderidae). Tesis de Posgrado. Pontificia Universidad Católica del Ecuador.

Barron GL, Dierkesy Y. 1977. Nematophagous fungi: Hohenbuehelia, the perfect state of Nematoctonus. Canadian Journal of Botany 55: 3054-3062. Doi: 10.1139/b77-345

Barron GL, Thorn RG. 1987. Destruction of nematodes by species of Pleurotus. Canadian Journal of Botany 65: 774-778. Doi: 10.1139/b87-103

Bellettini MB, Belletini S, Fiorda FA, Batch F, Fabela-Morón MF, Hoffman-Ribiani R. 2018. Diseases and pests noxious to Pleurotus spp. mushroom crops. Revista Argentina de Microbiología 50: 216-226. Doi: 10.1016/j.ram.2017.08.007

Byron AH, García-Castro FE, Cubides JA. 2018. 20 años de investigación en nematodos gastrointestinales de rumiantes. Conexión Agropecuaria 8: 352-355.

Camacho-Morales R, Gerardo LG, Navarro J, Sánchez JE. 2017. Ligninolytic enzyme production by white rot fungi during paraquat (herbicide) degradation. Revista Argentina de Microbiología 49: 189-196. Doi: 10.1016/j.ram.2016.11.004

Castañeda-Ramírez GS, Mendoza de Gives P, Aguilar-Marcelino L, López-Arellano ME, Hernández-Romano J. 2016. Phylogenetic analysis of nucleotide sequences from the ITS region and biological characterization of nematophagous fungi from Morelos, Mexico. Journal of Mycology: 8502629. Doi: 10.1155/2016/8502629

Castañeda-Ramirez GS, Torres-Acosta JFJ, Sánchez JE, Mendoza de Gives P, González-Cortazar M, Zamilpa A, Al-ani LKT, Sandoval-Castro C, de Freitas Soares FE, Aguilar-Marcelino L. 2020. The possible biotechnological use of edible mushroom bioproducts for controlling plant and animal parasitic nematodes. BioMed Research International: 6078917. Doi: 10.1155/2020/6078917

Choo HY, Kim HH, Lee HS, Lee SW, Park SH, Jin BR, Choo YM. 2001. Bio-logical control of Lycoriella mali (Diptera: Sciaridae), a pest ofoyster mushroom, Pleurotus ostreatus using entomopathogenic nematodes. Korean Journal of Applied Entomology 40: 5967.

Cuevas-Padilla EJ, Aguilar-Marcelino L, Sánchez JE, González-Cortázar M, Zamilpa-Álvarez A, Huicochea-Medina M, López-Arellano ME, Mendoza-de-Gives P, Hernández-Velázquez VM, González-Garduño R. 2018. A Pleurotus spp. hydroalcoholic fraction possess a potent in vitro ovicidal activity against the sheep parasitic nematode Haemonchus contortus. In: Sánchez JE, Mata G, Royse DJ (eds.), Updates on tropical mushrooms. Basic and applied research. 1st. Edition. El Colegio de la Frontera Sur, San Cristóbal de Las Casas. Pp. 193-211.

Cuevas-Padilla E. 2019. Evaluación in vitro de extractos crudos de Pleurotus sp., y la participación de sus proteínas contra Haemonchus contortus. Tesis de Maestría. Universidad Autónoma del Estado de Morelos, México.
Degenkolb T, Vilcinskas A. 2016. Metabolites from nematophagous fungi and nematicidal natural products from fungi as alternatives for biological control. Part II: metabolites from nematophagous basidiomycetes and non-nematophagous fungi. Applied Microbiology and Biotechnology 100: 3813-3824. Doi: 10.1007/ s00253-015-7233-6

Djian C, Pijarouvski L, Ponchet M, Arpin N. 1991. Acetic acid, a selective nematicidal metabolite from culture filtrate of Paecilomyces lilacinus Samsan and Trichoderma longibrachiatum. Nematologica 37: 101-102. Doi: 10.1163/187529291X00105

FAO. 2020. OCDE-FAO Perspectivas Agrícolas 2020-2028. OECDiLibrary. Doi: 10.1787/7b2e8ba3-es.

Fernández-Jiménez MA, Bulla-Castañeda DM, Sanabria-Villate AM, Pulido-Medellin MO. 2019. Implementación de hongos nematófagos para el control de parásitos gastrointestinales. Pensamiento y Acción 27: 7-20.

Figueroa-Antonio A, Pineda-Rodríguez SA, Godínez-Jaime F, Vargas-Álvarez D, Rodríguez-Bataz E 2018. Gastrointestinal parasite of bovine and caprine livestock in Quechultenango, Guerrero, México. Agro Productividad 11: 97-104.

Garcia-Lopes AC, Hiura E, Soares FE, Leandro AF, Sena C, Ferraz CM, Lacerda T, Senna T, Rocha A, Araújo AL, Araújo JV, Braga F. 2015. Predatory activity of the fungus Pleurotus eryngii on Ancylostoma caninum infective larvae. Soj Veterinary Sciences 20: 2-6. Doi: 10.15226/2381-2907/1/1/00104

Gasque R. 2008. Enciclopedia bovina. UNAM, México, D. F. Doi: 10.15226/2381-2907/1/1/00104

Gilbertson RL. 1981. North American wood-rotting fungi that cause brown rots. Mycotaxon 12: 372-416.

Gómez-Velázquez S. 2018. Efecto de extractos de cultivo sumergido de Pleurotus ostreatus, Pleurotus djamor y Pleurotus agaves sobre la activación in vitro de macrófragos. Tesis de Posgrado. Universidad Autónoma del Estado de Morelos, México.

González-Cortázar M, Sánchez JE, Huicochea-Medina M, Hernández-Velázquez VM, Mendoza-de-Gives P, Zamilpa A, López-Arellano ME, Pineda-Alegría JA, Aguilar Marcelino L. 2020. In vitro and in vivo nematicide effect of extract fractions of Pleurotus djamor against Haemonchus contortus. Journal of Medicinal Food. Doi: 10.1089/jmf.2020.0054

González-Garduño R, Torres-Hernández G, Nuncio-Ochoa MGJ, Cuéllar-Ordaz JA, Zermeño-García ME. 2003. Detección de eficiencia antihelmíntica en nemátodos de ovinos de pelo con la prueba de reducción de huevos en heces. Livestock Research for Rural Development 15: 12-15.

Gutiérrez C, Boza M, Pache S, Rollano M, Brígido M, Cabezas M. 2020. Nematodos en ganado ovino. Revista Meridies 23: 48-52.

Hibbet DS, Thorn RG. 1994. Nematode-trapping in Pleurotus tuberregium. Mycologia 86: 696-699.

Hyde KD, Swe A, Zhang KQ. 2014. Nematode-Trapping Fungi. In: Zhang K, Hyde KD (eds.) Nematode-trapping fungi: Fungal Diversity Research Series. Mushroom Foundation, Yunnan. Pp. 1-12. Doi: 10.1007/978-94-017-8730-7

Koitabashi M, Kajitani Y, Hirashima K. 2004. Antifungal substances produced by fungal strain Kyu-W63 from wheat leaf and its taxonomic position. Journal General. Plant. Pathology 70: 124-130. Doi: 10.1007/s10327-003-0095-2 
Kwok OC, Plattner R, Weisleder D, Wicklow DT. 1992. A nematicidal toxin from Pleurotus ostreatus NRRL 3526. Journal of Chemical Ecology 18: 127-136. Doi: 10.1007/BF00993748

Lanusse C, Sallovitz J, Bruni S. 2018. Antinematodal drugs. In: Reviere J, Papich M (eds.) Veterinary pharmacology and therapeutics. 10th edition. John Wiley \& Sons, Hobeken. Pp. 1035-80.

Lee C, Chang H, Yang C, Wali N, Shie J, Hsueh Y. 2020. Sensory cilia as the achilles heel of nematodes when attacked by carnivorous mushrooms. PNAS. 117: 6014-6022. Doi: 10.1073/ pnas. 1918473117

Li G, Dong J, Mo Y, Zhang KQ. 2001. Nematicidal activity of nematophagous Pleurotus and allied fungi to Panagrellus redivivus. Chinese Journal of Biological Control 17: 26-29.

Li, G., X. Wang, L. Zheng, L. Li, R. Huang, K. Zhang, 2007. Nematicidal metabolites from the fungus Pleurotus ferulae Lenzi. Annals of Microbiology 57: 527-529. Doi: 10.1007/BF03175350

Li HG, Zhang K. 2014. Nematode-toxic and their nematicidal metabolites. In: Zhang K, Hyde KD (eds.) Nematode-trapping fungi: Fugal diversity research. Mushroom Foundation, Yunnan. Pp. 313-375. Doi: 10.1007/978-94-017-8730-7

Li S, Shah NP. 2014. Antioxidant and antibacterial activities of sulphated polysaccharides from Pleurotus eryngii and Streptococcus thermophilus ASCC 1275. Food Chemistry 165: 262-270. Doi: 10.1016/j.foodchem.2014.05.110

Liébano EF, López-Arellano ME, Mendoza de Gives P, Aguilar-Marcelino L. 2011. Manual de diagnóstico para la identificación de larvas de nematodos gastrointestinales en rumiantes. Publicación Especial No. 2. Instituto Nacional de Investigaciones Forestales, Agrícolas y Pecuarias INIFAP, Cuernavaca.

Lobayan SI, Schapiro JH, Fiel CA, Zabalo MM, Roselli JG. 2017. Resistance to antiparasitics in cattle from northeast of Argentina. Revista Veterinaria 28: 1668-4834.

López-González JL, Huato MA, Álvarez F, Parra IF, Zuluaga GP. 2012. La economía de traspatio como estrategia de supervivencia en San Nicolás de los Ranchos, Puebla, México. Revista de Geografía Agrícola 48: 51-62.

Lumaret JP, Errouissi F, Floate K, Römbke J, Wardhaugh K. 2012. A review on the toxicity and non-target effects of macrocyclic lactones in terrestrial and aquatic environments. Current Pharmaceutical Biotechnology 13: 1004-1060. Doi: 10.2174/138920112800399257

Luo H, Liu Y, Fang L, Li X, Tang XN, Zhang KQ. 2007. Coprinus comatus damages nematode cuticles mechanically with spiny balls and produces potent toxins to immobilize nematodes. Applied and Environmental Microbiology 73: 3916-3923. Doi: 10.1128/ AEM.02770-06

Márquez-Lara D. 2013. Resistencia a los antihelmínticos en nematodos de rumiantes y estrategias de control. Colombia: Corporación Colombiana de Investigación Agropecuaria 1-166.

Martínez MI, Cruz RM. 2009. The use of agriculture and livestock chemical products in the cattle-ranching area of Xico, central Veracruz México, and their possible environmental impact. Acta Zoológica Mexicana 25: 637-681.

Mendoza-de-Gives P, Valero-Cross R. 2009. Uso de hongos nematofagos: una herramienta biotecnológica para el control de nematodos parásitos del ganado. Folleto técnico 7. Centro Nacional de Investigación Disciplinaria en Parasitología Veterinaria. Pp. $1-34$.

Mendoza-de-Gives P. 2020. Microorganismos en el manejo de parásitos de ganado. Folleto técnico en el Área de Helmintología. Centro Nacional de Investigación Disciplinaria en Parasitología Veterinaria. Pp. 1-4.

Montañez-Palma LF. 2020. Efecto del extracto hidroalcohólico del hongo comestible Neolentinus ponderosus sobre el nematodo Haemonchus contortus. Tesis de Maestría. Centro de Investigaciones Biológicas. Universidad Autónoma del Estado de Morelos, México.

Nordbring-Hertz B, Jansson HB, Tunlid A. 2006. Nematophagous fungi. In: Encyclopedia of life sciences. John Wiley \& Sons, Chichester. Pp. 145-179. Doi: 10.1038/npg.els.0004293

Olazarán-Jenkins S, López-Arellano ME, Cedillo-Borda M, Mendoza-de-Gives P, Olmedo-Juárez A. 2019. Eficacia antihelmíntica en campo por FECRT y confirmación de resistencia a bencimidazol por AS-PCR en nematodos de ovinos en Puebla, México. Revista Académica 12: 434-437.

Oropeza P. 2017. Productividad y actividad antioxidante de cepas silvestres, reconstituidas e híbridas de Pleurotus djamor. Tesis de Maestría. Universidad Tecnológica de la Mixteca, México.

Paredez-Martínez CP. 2014. Incidencia parasitaria gastrointestinal en la ganadería lechera de la hacienda Monte Carmelo. Tesis de Licenciatura. Universidad Tecnica de Ambato, Ecuador.

Pérez-Moreno J, Lorenzana Fernández A, Carrasco Hernández V, Yescas-Pérez A. 2010. Los hongos comestibles silvestres del Parque Nacional Izta-Popo, Zoquiapan y Anexos. Colegio de Posgraduados-SEMARNAT-CONACYT, Texcoco. Pp. 167-169.

Pineda-Alegría A, Sánchez-Vázquez JE, González-Cortazar M, Zamilpa A, López-Arellano ME, Cuevas-Padilla EJ, Mendoza-de-Gives P, Aguilar-Marcelino L. 2017. The edible mushroom Pleurotus djamor produces metabolites with lethal activity against the parasitic nematode Haemonchus contortus. Journal of Medicinal Food 20: 1184-1192. Doi: 10.1089/ jmf.2017.0031

Pineda-Alegría JA, Sánchez JE, González-Cortázar M, Von Son-de Fernex E, González-Garduño R, Mendoza-de Gives P, Zamilpa A, Aguilar-Marcelino L. 2020. In vitro nematocidal activity of commercial fatty acids and ?-sitosterol against Haemonchus contortus. Journal of Helminthology 94: e135. Doi: 10.1017/ S0022149X20000152

Pinilla JC, Flórez P, Sierra M, Morales E, Sierra R, Vásquez MC, Tobon JC, Sánchez A, Ortiz D. 2018. Prevalencia del parasitismo gastrointestinal en bovinos del departamento Cesar, Colombia. Revista de Investigaciones Veterinarias del Perú 16: 278-287.

Pino V, Silva-Aguayo G, Figueroa-Cares I, Gerding-González M, Loyola P, Castañeda-Ramirez GS, Aguilar-Marcelino L. 2019. In vitro efficacy of edible mushroom Pleurotus ostreatus kumm extracts for Sitophilus zeamais motschulsy control. Chilean Journal of Agricultural \& Animal Sciences 35: 293-303. Doi: 10.4067/ S0719-38902019005000505

Quevedo HJ, Llauradó MG, Bermúdez RC, Cos P. 2018. Evaluación de la actividad inmunomdouladora de bioporductos obtenidos de la seta comestible-medicinal Pleurotus ostreatus. Anales de la Academia de Ciencias de Cuba 8: 2-10. 
Quintero EZJ. 2018. Evaluación in vitro y en microparcelas del ácaro nematrófago Caloglyphus mycophagus con uso potencial contra tres nematodos de importancia agropecuaria Tesis de Licenciatura. Instituto Tecnológico Superior de San Miguel el Grande, México.

Ribeiro B, Rangel J, Valentão P, Baptista P, Seabra R, Andrade P. 2006. Contents of carboxylic acids and two phenolics and antioxidant activity of dried portuguese wild edible mushrooms. Journal of Agricultural and Food Chemistry 54: 8530-8537. Doi: 10.1021/jf061890q

Rinker DL, Olthof ThHA, Dano J, Alm G. 1995. Effects of entomopathogenic nematodes on control of a mushroom-infesting sciarid fly and on mushroom production. Biocontrol Science and Technology 5: 109-120. Doi: 10.1080/09583159550040051

Rodriguez-Martínez R, Mendoza de Gives P, Aguilar-Marcelino L, López-Arellano ME, Gamboa-Angulo M, Rosas-Saito GH, Reyes-Estebanez M, Garcia-Rubio R. 2018. In vitro lethal activity of the nemathopagous fungus Clonostachys rosea (Ascomycota: Hypocreales) against nematodes of dive different taxa. Biomed Research International 35: 18-27. Doi: 10.1155/2018/3501827

Rodríguez-Vivas RI, Grisi L, Pérez-León AA, Silva-Villela H, Torres-Acosta JF, Fragoso-Sánchez H, Romero-Salas D, Rosario-Cruz R, Saldierna F, García-Carrasco D. 2017. Potential economic impact assessment for cattle parasites in Mexico. Review. Revista Mexicana de Ciencias Pecuarias 8:1-14. Doi: 10.22319/ rmcp.v8i1.4305

Salmones D, Mata G. 2012. Ceparios de hongos en México. In: Sánches JE, Mata $G$ (eds.) Hongos comestibles y medicinales en Iberoamérica: investigación y desarrollo en un entorno multicultural. El Colegio de la Frontera Sur-Instituto de Ecología, A.C., Tapachula. Pp. 69-77.

Sánchez JE, Royse J. 2017. Microorganismos benéficos asociados a la micósfera de Pleurotus spp. In: Sánchez JE, Royse DJ (eds.) La biología, el cultivo y las propiedades nutricionales y medicinales de las setas Pleurotus spp. El Colegio de la Frontera Sur, San Cristóbal de Las Casas. Pp. 53-61.

Sánchez JE, Jiménez-Perez G, Liedo P. 2015. Can consumptions of antioxidant rich mushrooms extend longevity?: antioxidant activity of Pleurotus spp. and its effects on Mexican fruit flies (Anastrepha ludens) longevity. AGE 37: 107. Doi: 10.1007/s11357015-9847-0

Saumell C, Fusé L, Iglesias L, Fernández S, Fiel C. 2008. Enfoque bioecológico del potencial de los hongos nematófagos en el control biológico de tricostrongilídeos de rumiantes. Revista de Medicina Veterinaria Buenos Aires 89: 45-54.

Satou T, Kaneko K, Koike K. 2008. The toxin produced by Pleurotus ostreatus reduces the head size of nematodes. Biological and Pharmaceutical Bulletin 31: 574-576. Doi: 10.1248/bpb.31.574

SENASA. 2017. Manual de prevención y control de enfermedades parasitarias. Programa de incentivos a la mejora de la gestión municipal. Meta 37. Ministerio de Economia y Finanzas, Lima.
Sharma VP. 1994. Potential of Pleurotus sajor-caju for biocontrol of Aphelenchoides camposticola in Agaricus bisporus cultivation. Mushroom Research 3: 15-20.

Singh AU, Sharma K. 2016. Pests of mushroom. Advances in Crop Sciences and Technology 4: 213. Doi: 10.4172/23298863.1000213

Smiderle FR, Olsen LM, Caronero ER, Baggio CH, Freitas CS, Marcon R. 2008. Anti-inflammatory and analgesic properties in a rodent model of a linked $\beta$-glucan isolated from Pleurotus pulmonarius. European Journal of Pharmacology 597: 86-91. Doi: 10.1016/j. ejphar.2008.08.028

Stadler M, Mayer A, Anke H, Sterner O. 1994. Fatty acids and other compounds with nematicidal activity from cultures of Basidiomycetes. Planta Medica 60: 128-132. Doi: 10.1055/s-2006-959433

Sutherland I, Scott I. 2010. Gastrointestinal nematodes of sheep and cattle: biology and control. $1^{\text {st }}$ ed. Wiley-Blackwell, Oxford.

Thorn GR, Barron GL. 1984. Carnivorous mushrooms. Science 224: 76-78.

Torres-Acosta JF, Marbel S, Villarroel-Álvarez F, Rodríguez-Arévalo, Gutiérrez-Segura I, Alonso-Díaz MA. 2003. Diagnóstico de nematodos gastrointestinales resistentes a benzimidazoles e imidazotiazoles en un rebaño caprino de Yucatán, México. Revista Biomédica 14: 75-81. Doi: 10.32776/revbiomed.v14i2.344

Valcárcel-Sancho F, Rojo-Vázquez FA, Olmeda-García B, Arribas-Novillo L, Márquez-Sopeña N, Fernando P. 2009. Atlas de Parasitología Ovina. Editorial Servet, Zaragoza. Doi: 978-84-92569-05-2

Van den Hoogen J, Geisen S, Crowther TW. 2019. Soil nematode abundance and functional group composition at a global scale. Nature 572: 194-198. Doi: 10.1038/s41586-019-1418-6

Von Son-De-Fernex E, Díaz MA, Mendoza-Gives P, Valles-de-la Mora B, Zamilpa A, González-Cortázar M. 2016. Actividad ovicida de extractos de cuatro especies de plantas contra el nematodo gastrointestinal Cooperia punctata. Veterinaria México OA 3: 10-15. Doi: 10.21753/vmoa.3.2.365

Widiarso PB, Kurniasih PJ, Nurcahyo W. 2018. Morphology and morphometry of Haemonchus contortus exposed to Gigantochloa apus crude aqueous extract. Veterinary World 11: 921-925. Doi: 10.14202/vetworld.2018.921-925

Xiang HQ, Feng ZX. 2001. The nematicidal toxicity of the fruit bodies of Pleurotus ostreatus. Journal of Shenyang Agricultural University 32: 173-175.

Zajac MA, Garza J. 2020. Biology, Epidemiology, and control of gastrointestinal nematodes of small ruminants. Veterinary Clinics Food Animal 36: 73-87. Doi: 10.1016/j.cvfa.2019.12.005

Zhang Y, Li GH, Zhang KQ. 2011. A review on the research of nematophagous fungal species. Mycosystema 30: 836-845. 